\title{
HAMBATAN KOMUNIKASI ANTARBUDAYA MAHASISWA THAILAND DI JEMBER
}

\author{
Hery Bambang Cahyono \\ Prodi Ilmu Komunikasi Fakultas Ilmu Sosial dan Ilmu Politik \\ Universitas Muhammadiyah Jember \\ herybcahyono@gmail.com
}

\begin{abstract}
Thai students, who are studying in the city of Jember, experience many communication barriers. Though the communication factor is very influential on the success in the learning process. So this research wants to know the barriers of intercultural communication and how to solve these obstacles. The theory used is a theory relating to intercultural communication barriers. The research method used was qualitative descriptive, while the informants were Thai students who attended Muhammadiyah Jember University. The results of the study showed that the language factor became the main obstacle both academically and non-academically. Furthermore, cultural differences that can be in the form of food, drink, business and communication ethics are also obstacles to intercultural communication.
\end{abstract}

Keywords: Obstacles, Thai Students, Intercultural Communication

\begin{abstract}
ABSTRAK
Mahasiswa Thailand, yang sedang belajar di kota Jember mengalami banyak sekali hambatan komunikasi. Padahal faktor komunikasi sangat berpengaruh pada keberhasilan dalam proses belajar. Maka penelitian ini ingin mengetahui hambatan komunikasi antarbudaya dan bagimana memecahkan hambatan tersebut. Teori yang dipakai adalah teori yang berkenaan dengan hambatan komunikasi antarbudaya. Metode penelitian yang dipakai adalah deskriptifyang bersifat kualitatif, sedang yang menjadi informan adalah mahasiswa Thailand yang kuliahi Universitas Muhammadiyah Jember. Hasil penelitian menunjukan bahwa faktor bahasa menjadi kendala utama baik secara akademik maupun non akademik. Selanjutnya perbedaan budaya yang dapat berupa makanan, minuman, busaha dan etika komunikasi juga merupakan hambatan komunikasi antarbudaya.
\end{abstract}

Kata kunci : Hambatan, Mahasiswa Thailand, Komunikasi Antarbudaya

\section{PENDAHULUAN}

Mahasiswa asing yang datang ke Jember tersebar di banyak perguruan tinggi negeri dan swasta. Sederetan perguruan tinggi itu antara lain Universitas Jember, STAIN, Universitas
Muhammadiyah, STE Mandala dan beberapa perguruan tinggi yang lain. Mahasiswa Thailand ini masuk ke Universitas Muhammadiyah Jember melalui dua jalur yakni mendapatkan beasiswa dan jalur dari Ikatan Badan 
Alumni ( IBA ) Thailand. Jumlah mereka lumayan banyak yaitu 31 mahasiswa. Mereka tersebar di beberapa fakultas yaitu: FISIP, FKIP, Teknik, Ekonomi dan fakultas lainnya. Dengan datangnya mahasiswa Thailand ini menambah nuansa perbedaan kebudayaan di kota Jember termasuk Universitas Muhammadiyah Jember ini makna pesan dari proses komunikasi yang berbeda latar belakang budayanya.

Banyak sekali hambatan komunikasi yang harus dihadapi oleh mahasiswa asal Thailand yang ada di Jember. Bahasa yang berbeda, menjadi kendala yang sangat berarti mengingat mereka kebanyakan berbahasa Thai. Kesulitan itu masih bisa dikurangi karena kebanyakan dari mereka banyak yang bisa berbahasa Melayu. Karena kebanyakan mereka datang dari negara bagian Patani Thailand selatan yang dekat dengan Malaysia. Hal itu sungguh berbeda bagi mahasiswa Thailand yang tidak berlatar belakang bahasa Melayu. Selain itu mahasiswa Thailand yang ada di Jember juga menghadapi masalah kebudayaan yang cukup berarti. Mulai dengan pakain, makanan, etika dan juga masalah sosial yang lain. Akhirnya hambatan komunikasi antarbudaya tersebut terutama bahasa akan berakibat pada kendala akademik dan kebudayaan.
Berdasarkan latar belakang kondisi tersebut di atas, maka dapat dikemukakan permasalahan yang layak untuk diteliti ini adalah sebagai berikut :

1) Apa sajakah kendala komunikasi antarbudaya yang dihadapi mahasiswa Thailand di Universitas Muhammadiyah Jember?

2) Bagaimanakah mahasiswa Thailand di Universitas Muhammadiyah Jember menyelesaikan hambatan komunikasi tersebut?

\section{Hambatan komunikasi antarbudaya}

Proses komunikasi tidak selamanya berjalan lancar sesuai dengan keinginan orang yang berkomunikasi baik sebagai pengirim ataupun penerima. Bahkan masing-masing unsur komunikasi mempunyai hambatan yang berasal dari masyarakat sekitar maupun dari dirinya sendiri. Hambatan komunikasi itu ada;ah sebagai berikut :

\section{Kebahasaan}

Komunikasi verbal merupakan merupakan sarana yang sangat efektif untuk menyampaikan pesan dari komunikator kepada komunikan. Bahasa menjadi sarana kunci untuk mengemas pesan yang efektif. Akan tetapi tidak cukup hanya pesan verbal tetapi juga pesan 
nonverbal. Dari hubungan inilah masalah budaya menjadi sangat berpengaruh, karena bahasa adalah bagian dari unsur budaya. Atau bisa juga dikatakan bahwa bahasa adalah refleksi budaya. Banyak data menunjukan bahwa bahasa menjadi ciri dari sebuah kebudayaan.

Bahasa tidak sebatas sarana untuk menyampaikan pesan akan tetapi juga merupakan penciri atau identitas sebuah komunitas. Indonesia menguatkan jati dirinya dengan menggunakan Bahasa Indonesia sekalipun sebanarnya tidak jauh dengan bahasa Melayu. Akhirnya Bahasa Indonesia mampu berfungsi mempererat identitas sebagai sebuah bangsa yang majemuk. Tidak u kalau seseorang menggunakan bahasa tertentu untuk mengetuk emosi seseorang.

Bahasa bisa juga sebagai sebuah ekspresi. Dengan menggunakan bahasa seseorang mengungkapkan isi hatinya, idenya dan apa saja yang ingin diungkapkan. Memilih kata yang indah dan sesuai kemudian menyusun dalam bentuk kalimat yang runtut sehingga mudah dipahami dan mempunyai nilai seni yang tinggi. Bahasa adalah sarana atau media bagi manusia untuk mengungkapkan suatu gagasan(Liliweri, 1994:1-2).
Bahasa juga berkaitan erat dengan persepsi. Bagaimanakah persepsi terhadap simbul-simbul yang diciptakan lingkungan sosial maupun lingkungan fisik. Apa yang terucap tergantung bagaimana seseorang memahami simbul-simbul tersebut. Bahasa akan menterjemahkan dan mengungkapkan apa yang ada dalam diri manusia. Sedang bahasa sendiri mempunyai kaedah dan stuktur sendiri yang berbeda dengan yang lain.

Dalam berkomunikasi manusia menggunakan bahasa verbal dan bahasa nonverbal, sedang komunikasi verbal menggunakan bahasa verbal dan bahasa tulisan (Ronald B.Adler dan George Rodman dalam Sasa Djuarsa 1994:256). Karena itu seorang komunikator membutuhkan pengetahuan tentang bentuk-bentuk pesan verbal, yang terdiri dari;

a) Struktur pesan: ditunjukkan oleh pola penyimpulan (tersirat atau tersurat), pola urutan argumentasi (mana yang lebih dahulu, argumentasi yang disenangi atau yang tidak disenangi), pola obyektivitas (satu sisi atau dua sisi).

b) Gaya pesan: menunjukkan variasi linguistik dalam penyampaian pesan (perulangan, mudah dimengerti, perbendaharaan kata). 
c) Daya tarik pesan: mengacu pada motif-motif psikologis yang dikandung pesan (rasional-emosional, daya tarik ketakutan, daya tarik ganjaran).

Perpaduan penggunaan bahasa dengan teknologi akan membantu mahasiswa untuk memahami makna dan maksud dalam sebuah proses belajar seperti di dalam kampus. Menu dalam sebuah program komputer menjadi lebih mudah dipahami karena menggunakan simbul-simbul. Mahasiswa asal Thailant akan lebih mudah menjalankan tugas walaupun bahasanya berbeda karena dibantu oleh lambang-lambang yang ada di program layanan akademis.

Bahasa verbal tidak selengkap bahasa nonverbal. Bahasa verbal seringkali bersifat ambigu hanya melawankan seperti besar dan kecil, jauh dan dekat, hitam dan putih. Sedangkan dalam alam nyata seringkali antara keduanya atau lebih dari kedunya. Agak kecil agak besar, atau lebih besar atau lebih kecil. Kesemuanya itu perlu bantuan bahasa nonverbal.

Komunikasi efektif tidak cukup hanya mengandalkan bahasa lisan tetapi harus didukung oleh bahasa verbal yang mempunyai tiga bentuk yaitu: a) Kinesik

Pesan-pesan kinesik berkaitan dengan pesan yang disampaikan melalui gerakan tubuh/anggota tubuh, misalnya emblem, illustrator, adaptor, regulator, dan affect display.

b) Proksemik

Pesan-pesan proksemik pada prinsipnya ditunjukkan melalui pemeliharaan jarak fisik tatkala kita berkomunikasi, misalnya jarak intim, pribadi, kelompok, dan jarak dengan khalayak. Dikelompokkan pula pesan melalui penataan ruang dan pilihan waktu.

c) Paralinguistik

Pesan-pesan paralinguistik melalui penampilan kualitas suara, ciri-ciri vokal, pembatasan vokal, dan pemisahan vokal.

\section{Hambatan komunikasi antarbudaya}

Hambatan komunikasi antarbudaya bisa datang dari komunikator dan juga oleh komunikan. Perbedaan budaya menjadi salah satu hambatan yang sangat prinsip karena komunikasi diwarnai oleh budaya. Dalam masyarakat Indonesia mengangguk bermakan setuju atau ya, akan tetapi dalam budaya lain bisa sebaliknya. Lebih terinci hambatan komunikasi itu adalah sebagai berikut: 
1) Tujuan komunikasi yang berbeda

Bukan rahasia lagi bahwa dalam berkomunikasi banyak sekali motivasi yang ada pada masing-masing yang berkomunikasi. Ada sebagian yang ingin asimila ada sebagian yang lain justru sebaliknya yaitu ingin budayanya sendiri yang berkembang.

2) Etnosentrime

Etnosentrime juga menjadi masalah komunikasi antarbudaya yang tidak kalah sulitnya. Etnosentrime sama dengan menutup pintu untuk bertemunya budaya yang berbeda. Budayakulah yang paling bagus, budayakulah yang layak berkembang sedang lain tidak layak.

3) Tidak adanya saling percaya

Komunikasi adalah proses penyampaian pesan. Bila kepercayaan tidak ada maka sangat sulit komunikasi itu berjalan efektif. Mustahil akan lehir persatuan, kekompakan dalam sebuah masyarakat. Apalagi dalam masyarakat negara yang majemuk seperti Indonesia.

\section{4) Menarik diri}

Istilah ini muncul ketika dalam proses komunikasi salah satu unsur yang terlibat menarik diri bisa karena tidak setuju, atau bisa juga faktor lain seperti rasa takut akan budayanya yang terpengaruh oleh budaya yang terlibat dalam proses komunikasi.
5) Kecilnya empati

Empati adalah masalah psikologi yang sangat berpengaruh. Empati yang besar akan dapat menyelesaikan masalah komunikasi yang rumit, karena yang berbicara adalah hati dan rasa. Banyak dijumpai dalam masyarakat tradisional faktor empati menjadi perekat budaya yang sangat kuat. Dengan pelan tetapi pasti solidaritas sosial tumbuh dan berkembang menjadi suatu masyarakat yang kompak.

\section{Gegar budaya}

Gegar budaya dalam bahasa Inggris disebut dengan culture shock, adalah sebuah istilah psikologi yang mendeskripsikan keadaan psikologis seseorang dalam menghadapi budaya yang berbeda dengan budaya yang dimiliki dimana seseorang itu biasa tinggal. Tingkat keadaannya berbeda antara individu satu dengan yang lain. Bisa juga seseorang dengan mudah menyesuaikan diri dengan budaya yang baru, tetapi bisa juga sebaliknya. Keadaan ini menjadi kendala komunikasi yang sangat prinsip bagi siapapun juga yang memasuki budaya baru.

\section{METODE}

Penelitian ini menggunakan pendekatan kualitatif. Informan dalam 
penelitian ini adalah mahasiswa asal Thailand yang sedang belajar di Universitas Muhammadiyah Jember. Penentuan sumber data dengan menggunakan teknik purposive sampling. Teknik pengumpulan data dengan metode wawancara, dokumentasi observasi non partisipan.

\section{PEMBAHASAN}

\section{Hambatan komunikasi mahasiswa asal}

Thailand

Menurut data yang bersumber dari KUI (Kantor Urusan Internasional) UM Jember, jumlah mahasiswa asing yang berasal dari Negara Thailand merupakan mahasiswa terbanyak dengan jumlah total 31 orang. Mereka tersebar dibeberapa fakultas, diantaranya Fakultas keguruan dan pendidikan (FKIP), Fakultas Kesehatan (FIKES), Fakultas Teknik, Fakultas Ilmu sosial dan Ilmu Politik. Para mahasiswa asing yang berasal dari negara Thailand ini mulai ada di kampus UM Jember sejak tahun 2013.

Mahasiswa UM Jember yang berasal dari Thailand mayoritas adalah dari daerah Thailand selatan yaitu Patani. Daerah tersebut secara sosial-kultural masih dekat dengan budaya Malaysia dan Indonesia atau lebih luas disebut dengan budaya Nusantara. Banyak diantara mereka yang fasih dalam berbahasa Melayu model Malaysia, akan tetapi juga ada beberapa yang tidak lancar bahkan juga ada yang tidak bisa berbahasa Melayu sama sekali. Gambaran di atas menunjukan adanya kendala komunikasi ketika menenpuh pendididikan di Universitas Muhammadiyah Jember.

\section{Hambatan akademik}

Hambatan komunikasi yang dihadapi mahasiswa asal Thailand Kegiatan akademik meliputi semua kegiatan yang berkaitan dengan perkuliahan yang biasa disebut dengan Tri Darma Perguruan Tinggi atau dilingkungan Universitas Muhammadiyah Jember disebut dengan Catur Darma karena ditambah dengan keislaman. Hambatan itu banyak berpusat kebahasaan.

\section{Penguasaan matari}

Umumnya mereka kurang memahami Bahasa Indonesia walaupun di kampung halamannya telah terbiasa menggunakan Bahasa Melayu yang lebih dekat ke Malaysia. Ketika berkomunikasi dengan dosen pada saat kuliah dan juga diluar kuliah mereka dihadapkan pada kendala bahasa. Dari sepuluh mahasiswa asal Thailand yang berasal dari sepuluh 
prodi di Universitas Muhammadiyah Jember menyatakan adanya kendala bahasa dalam berkomunikasi. Mahasiswa prodi matematika menyampaikan; "Untuk dengan dosen bahasa dalam berkomunikasi dalam bahasa Indonesia tidak sulit untuk dipahami, tetapi bila memakai bahasa yang lain itu kurang bisa ditangkap”. (Waesaripah Lohsatae). Tidak jauh berbeda dengan penuturan mahasiswa PAUD; "Kadang-kadang ketika berkomunikasi dengan dosen saya merasa menggunakan bahasa yang tidak sesuai, dengan karena saya kurang tahu kalimat yang benar”. (Sahuince Samae). Hal senada juga disampaikan oleh mahasiswa prodi Bahasa dan Sastra Indonesia; "Kadang-kadang ketika berkomunikasi dengan dosen kata-kata yang disampaikan tidak sesuai“" (Nurulhuda Dueromae).

Penuturan di atas menunjukan bahwa ketika mahasiswa asal Thailand berkomunikasi dengan dosen mengalami kendala bahasa. Pemakain bahasa nasional yaitu Bahasa Indonesia memang sedikit berbeda dengan Bahasa Melayu yang mereka pakai di Thailand khususnya di daerah selatan. Bahasa Melayu yang mereka gunakan lebih dekat kepada bahasa orang Melayu Malaysia, sedang bahasa Indonesia telah mendapatkan pengkayaan dari bahasa daerah yang tersebar luas seperti Bahasa Jawa, Sunda dan bahasabahasa daerah yang lain.

Mahasiswa asal Thailand yang kuliah di UNMUH Jember tidak saja dihadapkan pada perbedaan bahasa Indonesia dengan Bahasa Melayu akan tetapi seringkali dosen menggunakan bahasa lokal menurut penuturan mereka atau bahasa daerah menurut istilah orang Indonesia. Seperti penuturan mahasiswa prodi Teknik Sipil; “Ada juga terkadang dosennya menggunakan bahasa lokal untuk berkomunikasi tetapi tidak begitu banyak..." (Anas). Hal senada juga disampaikan oleh mahasiswa prodi Bahasa Inggris; "Ketika berkomunikasi dengan dosen saya merasakan menggunakan bahasa informal karena saya kurang mengerti kalimat-kalimat atau katakata..." (Suhainee Walhi). Bahkan ada juga yang bisa menunjuk bahwa dosen yang bersangkutan menggunakan Bahasa Jawa seperti disampaikan oleh mahasiswa prodi Manajemen; "Dosen berbicara secara cepat dan kadang menggunakan Bahasa Jawa pastilah saya tidak paham artinya" (Tirmizi).

Wawancara di atas menunjukan bahwa mahasiswa asal Thailand yang kuliah di UNMUH Jember mengalami kendala berkomunikasi dari aspek penggunaan bahasa daerah yang 
digunakan oleh dosen ketika mahasiswa asal Thailand yang kuliah di menyampaikan kuliah dan juga UNMUH Jember.

komunikasi interpersonal. Sebagai dosen, peneliti juga sangat membenarkan kesulitan tersebut di atas. Seringkali dosen sengaja atau tidak menggunakan bahasa daerah untuk berkomunikasi, bisa karena ingin menggambarkan secara jelas tentang suatu obyek, karena dalam bahasa resti tidak didapati. Bisa juga dosen yang bersangkutan ingin lebih akrap ketika berkomunikasi. Keadaan ini kurang disadari bahwa mahasiswanya tidak saja dari dalam negeri khususnya Jawa Timur tetapi juga ada yang dari luar negeri.

Kendala kebahasaan yang mereka hadapi berkaitan dengan kebahasaan adalah bahwa mahasiswa asal Thailand merasa cepat bila dosen berkomunikasi, sehingga sulit ditangakap. Seperti penuturan mahasiswa prodi Managemen yang bernama Tirmidi. Akan tetapi hanya sedikit yang mengalami hambatan kebahasaan dari aspek kecepatan, akan tetapi berbeda ketika berkomunikasi dengan teman kuliah. Komunikasi nonformal menjadikan mereka tidak mengontrol kecepatan dalam berbicara sehingga kurang bisa dipahami oleh lawan bicara yang mempunyai bahasa berbeda. Dari gambaran di atas dapat dilihat bahwa aspek kebahasaan menjadi kendala bagi

\section{Pemahaman terhadap buku/reverensi}

Kendala yang tidak kalah pentingnya adalah kendala komunikasi yang berkaitan dengan pemahaman terhadap buku, majalah dan sumber media cetak yang lain. Mahasiswa asal Thailand dari prodi Keperawatan menyampaikan; "Hambatan dengan dari buku berupa kata-kata ilmiah yang harus saya terjemahkan terlebih dahulu atau kepada mbak-mbak..." (Nasihah C.). Sedang mahasiswa mengungkapkan dengan ungkapan yang sedikit berbeda; "Beberapa buku yang membuat saya kurang memahami dengan bahasa yang tinggi" (Anisa Borthoh). Sedang mahasiswa yang lain melukiskan sedikit berbeda seperti penuturan Tirmizi; "... yang digunakan oleh bahasa penulis buku biasanya bahasa ilmiah yang berbeda dengan bahasa gaul". Bahkan mahasiswa asal Thailand menjelaskan menjelaskan; "Misalkan dalam buku ada pepatah yang tidak tau atau kurang paham" (Weasaripah Lohsatae).

Hasil wawancara di atas menunjukan bahwa berkaitan dengan buku-buku dan media cetak yang lain juga mengalami kendala. Padahal dalam proses belajar bahasa sangat mempengaruhi prestasi. 
Kendala seperti di atas hampir dialami oleh mahasiswa asal Thailand hanya cara pengungkapanya yang berbeda. Bisa jadi kendala tersebut muncul dari perbedaan Bahasa Melayu yang mereka gunakan dengan Bahasa Indonesia yang digunakan para penulis dalam menuangkan ideidenya di buku.

\section{Tugas akademik}

Tugas akademik yang dimaksud meliputi membuat makalah, menjawab soal ujian, tugas akhir yang banyak berkaitan dengan penulisan. Ternyata hasil penelitihan menunjukan ketika mahasiswa asal Thailand harus mengerjakan dan menjawab soal ujian sungguh mengalami kesulitan. Mahasiswa prodi Teknik Sipil mengungkapkan;” Bahasa adalah hambatan yang paling menjadi masalah terhadap hal ini dan juga cara-cara susun kata-kata”(Anas). "Bagi saya bicara dan menulis menjadi hambatan yaitu adalah bicara dan menulis, karena saya masih kurang tentang cara-cara ini..."'(Suhainee Wachi) mahasiswa prodi PAI. “ Ini sangat menjadi hambatan bagi kami anak Thailand karena bahasa yang akan menjawab dalam ujian itu bukan bahasa yang kami gunakan dalam sehari-hari harus menggunakan bahasa ilmiah", demikian tuturan Hammedee Tosae prodi
Ilmu Komunikasi. Hasil wawancara tersebut menunjukan bahwa kesulitan yang mereka hadapi ketika mengerjakan tugas dan menjawab soal ujian adalah sulitnya untuk menuangkan ide dan gagasan dan eksprsi yang lain dalam bentuk tulisan.

Hambatan ini akan dihadapi secara lebih nyata ketika mengerjakan tugas akhir atau skripsi. Karena menuangkan sebuah ide atau mendeskripsikan sebuah data sudah barang tentu berkaitan dengan penguasaan bahasa. Sulit kiranya orang yang kurang mumpuni dalam bahasa kemudian harus berhadapan dengan pekerjaan tulis-menulis. Kesulitan itu akan bertambah sulit bila nanti dikaitkan dengan membuat latar belakang masalah, kerangka teori, metodologi hingga olah data.

\section{Penggunaan teknologi informasi}

Hambatan komunikasi yang berasal dari penggunaan teknologi informasi atau biasa disebut dengan SIA hampir tidak dijumpai. Mahasiswa teknik sipil mengungkapkan; "Untuk SIA sudah cukup baik”. Kemudian dia melanjutkan;”... terkadang bahasanya aneh" (Anas). Informan yang lain menuturkan bahwa SIA sudah cukup memadai hanya kendala bukan pada bahasa tetapi pada lemotnya 
sinyal yang ada di kampus. Mahasiswa PAI menyampaikan;” ...internet sangat lemah membuat saya cari data untuk membikin tugas itu tidak bisa"(Kantatee Yaengkhunohao). Dalam bahasa yang lain ada sedikit mengeluh tentang penggunaan bahasa dan aplikasinya.

Beberapa uraian di atas hanyalah catatan yang sifatnya sangat pelengkap, akan tetapi banyak informan yang menyatakan bahwa SIA tidak menjadi hambatan yang berarti. Bila dianalisa maka aplikasi di dalam SIA adalah aplikasi yang umum dipakai dihampir semua perguruan tinggi di dunia, hanya bahasanya yang berbeda dan aplikasinya yang juga mungkin sedikit berbeda.

\section{Hambatan non akademik}

Hambatan non akademik menjadi daya tarik tersendiri bila diamati. Karena banyaknya ragam masalah yang muncul yang bisaa didekati dari banyak aspek tidak saja komunikasi tetapi juga budaya, spikologi hingga sosiologi. Akan tetapi hambatan itu diletakan secara proporsional karena mahasiswa Thailand yang ada di UNMUH Jember adalah kuliah, mencari ilmu yang sarat dengan pendekatan akademik.

Hambatan non akademik yang dimaksud adalah hambatan dalam berkomunikasi dengan lingkungan pada umumnya. Hambatan itu bersumber yang berkaitan dengan pergaulan sehari-hari seperti cara berpakaian, bahasa, etika komunikasi, makanan dan menuman.

\section{Pakaian}

Sungguh mencengangkan pandangan mahasiswa asal Thailand berkaitan dengan pakaian. Tepatnya bukan mencengangkan tetapi memalukan. Dari sepuluh informan hampir semuanya berkomentar miring tentang pakaian muslimah yang menurut mereka sangat seksi. Berbeda dengan dinegaranya yang berpaian lebih syar`i tidak seksi. Untuk memudahkan penyajian data saya tulis sebagai berikut:

a) Hammedee Tosae (komunikasi) ; "Berkaitan dengan pakaian pada awal saya masih heran, orangnya muslim tetapi berpakaian seksi buka aurot, kalai di Thailand kalau oragnya berpakaian tidak tutup aurot jelas di non Islam".

b) Tirmizi (manajemen) ; "Orang muslim tetapi pakaiannya seksi seperti tidak menutup aurot".

c) Suhainee Wachi (bahasa Inggris); "Kebanyakan yang dipakai pemudi di sini tidak sesuai dengan ajaran Islam”. 
d) Anas (teknik sipil); "Terkadang orang muslim tetapi tidak beraurot dan fashion yang tidak sama dengan orang asing seperti saya”.

e) Nurulhuda Dueramae (bahasa Indonesia); "Pakaian yang dipakai pemudi di sini sangat ketat dan tidak sesuai dengan ajaran Islam”.

f) Suhaince Samae (PAUD); "Pakaian yang dipakai oleh pemudi di sini sangat ketat dan tidak sesuai dengan ajaran Islam dan terlalu bebas".

Sebenarnya telah sering para dosen dan juga penyelenggara pendidikan di UNMUH Jember untuk lebih syar`i dalam berbusana. Akan tetapi pakaian yang mendekati syar’i masih kalah dengan pakaian midel barat yang seringkali identik dengan pakaian yang seksi dan ketat. Dari paparan di atas jelas masalah pakaian menjadi sebuah hambatan komunikasi atau bukan sangat tergantung pada mahasiswanya.

\section{Bahasa}

Sesuai dengan hambatan akademik dari aspek juga menjadi kendalam dalam berkomunikasi dengan orang lain. Apalagi dalam kehidupan sosial masyarakat yang dipakai tidak saja bahasa Indonesia tetapi juga bahasa daerah yaitu Madura dan Jawa. Betapa sulinta mahasiswa asal
Thailand prodi managemen menyampaikan; "Kadang saya mempergunakan bahasa etnis Melayu saya sendiri dalam kalimat Indonesia yang saya tidak tahu, dan kadang-kadang Bahasa Indonesiayang saya biacara sama buat yang kurang paham" (Tirmizi).

Ada juga yang cenderung diam karena malu berkata seperti penuturan mahasiswa PAI:" ... dalam berkomunikasi dengan lingkungan yaitu saya kurang berbicara dan malu dengan lingkungan"(KantateeYaengkhunohao).

Lain hal dengan apa yang disampaikan oleh mahasiswa FKIP Bahasa Inggris;" Bahasa yang digunakan kurang jelas bagi mereka dan sangat sulit untuk menyampaikan". Tidak sedikit yang menyebutkan kekesalannya dengan penggunaan bahasa daerah, seperti penuturan mahasiswa teknik sipil;" Sikap kaku, cara-cara berkomunikasi dan bahasa lokal" (Anas).

Berbagai macam ungkapan tersebut menunjukan bahwa mahasiswa asal Thailand yang kuliah di UNMUH Jember menghadapi kendala bahasa dalam berkomunikasi dengan lingkungan sosial. Kesulitan itu masih harus ditambah dengaan penggunaan bahasa lokal (Madura, Jawa) dalam berkomunikasi. 


\section{Makanan dan minuman}

Lain padang lain belalang lain lubuk lain ikanya itulah kata peribahasa. Bahwa masing masing daerah mempunyai adat istiadat, cara dan juga masakan yang berbeda-beda. Ketika seseorang memasuki daerah baru, maka masalah masakan menjadi kendala yang tidak bisa diabaikan. Jangankan lintas bangsa lintas suku saja dapat merasakan bedanya seperti layaknya orang Madura baru berpindah ke Jogja, maka makanan adalah menjadi kendala pertama.

Tidak berbeda dengan mahasiswa Thailand mereka juga mengelami hal serupa. Mahasiswa ilmu komunikasi menyampaikan;" ... minuman banyak yang aneh dilidah demikian juga makanan"(Hammedee Tosae), Tirmizi menyampaikan:" Makanan dan minuman membuat bosan dan barangnya kotor, Rasa masakanya hambar, manis tidak interesting”. "Bagi saya masakan di sini di Indonesia itu saya kurang suka karena merasakan berbeda dengan di negara saya dan saya sulit untuk mencari makanan yang cocok bagi saya"(Sahainee Wachi).

\section{Etika komunikasi}

Hasil wawancara berstruktur menunjukan hampir semua mahasiswa asal Thailand mengalami kendala etika komunikasi. Sebenarnya kendala tersebut tidak saja dialami oleh mahasiswa asal Thailand saja, karena banyak sekali mahasiswa yang banyak bersentuhan dengan HP kurang bisa menerapkan etika komunikasi dalam pergaulan terutama kepada orang yang lebih senior.

Mahasiswa PAI menyampaikan;" Yaitu saya tidak paham budaya Indonesia. Ketika saya berkomunikasi dengan orang tua atau tetangga saya kan berbicara seperti teman biasa"(Kantatee Yaengkhunohao). “ Mungkin terkadang saya tidak tahu cara apabila kita berkomunikasi dengan orang yang lebih tua dan adab-adabnya" Suhaince Samae (PAUD). " Untuk etika atau tata krama kadang-kadang saya kurang tahu tentang adat dengan orang tua karena ada yang berbeda dengan negeri saya"(Nurulhuda Dueromae, Bahasa dan Sastra Indonesia). Hasil wawancara menunjukan jawaban yang hampir sama.

Etika komunikasi wajar menjadi kendala komunikasi karena etika dibatasi oleh budaya dan wilayah. Artinya etika komunikasi hanya berlaku di bangsa Indonesia dan wilayahnya. Sedang di Thailand tentu berbeda dalam berkomunikasi kepada orang yang lebih tua atau dengan sesama. 
Cara mengadapi hambatan komunikasi

Mahasiswa asal Thailand dalam menghadapi kendala akademik yang berkaitan dengan dengan kendala bahasa umumnya memecahkannya dengan cara yang relatif sama yaitu banyak berkomunikasi. Nurulhuda Dueromae, Bahasa dan Sastra Indonesia menuturkan;" Saya memecahkan masalah dengan banyak berkomunikasi dengan temanteman dan belajar bahasa yang benar untuk untuk berkomunikasi dengan dosen, orang tua dan lain-lain". "Kalau tentang bahasa menurut saya harus berkomunikasi dengan teman-teman sebanyak banyaknya." (Nasuhah C, Keperawatan). "Saya memecahkan masalah dengan banyak berkomunikasi dengan temanteman dan belajar bahasa yang benar dengan kakak tingkat"(Suhainee Samae, PAUD). Dan juga ada yang memecahkan masalah bahasa dengan bertanya kepada kakak tingkat.

Ketika menghadapi kendala yang berkaitan dengan buku, merekapun memecahkan masalah relatif sama yaitu dengan bertanya kepada teman dan mencari bantuan juru penterjemah ulung google. Ketika berhadapan dengan masalah tugas seperti ujian, skripsi dan lain-lain jawabanya beraneka ragam. “Kalau tugas saya bertanya kepada teman, sedang dalam ujian saya menggunakan bahasa apasaja, terkadang bahasa Melayu" (Hemmedee Tosae, Ilmu Komunikasi). Tirmizi mahasiswa managemen menyampaikan;" Banyak membaca buku ilmuah dan ketika buat tugas bergaulan dengan orang Indonesia...". Dari jawaban yang berbeda tersebut yang sering dilakukan untuk memecahkan masalah adalah dengan bertanya kepada teman.

Hambatan non akademik umumnya berkaitan dengan bahasa. Sedang yang berkaitan dengan pakaian hampir tidak ada masalah bahkan ada yang menyampaikan banyak kesamaan antara pakaian Indonsia dengan Thailand khususnya yang beragama Islam. Hanya hampir semua informan menyebutkan bahwa ada perbedaan yang cukup prinsip antara muslim Thailand dengan muslim Indonesia. Bila di Thailand ada orang berpakaian seksi mesti non Islam akan tetapi di Indonesia walaupun Islam tetapi pakaiannya sangat ketat dan seksi.

Hemmedee Tosai mahasiswa Ilmu Komunikasi menyampaikan;" Berkaitan dengan pakaian pada awal saya merasa heran orangnya Muslim tetapi pakaiannya seksi. Kalau di Thailand orang berpakaian tidak tutup aurot jelas dia non muslim". Lebih jelas Suhainee Wachi 
menyampaikan;" Kebanyakan yang dipakai pemudi di sini tidak sesuai dengan ajaran Islam". Jawaban senada juga disampaikan oleh Nurulhuda Dueromae mahasiswa Bahasa Indonesia;" Pakaian yang dipakai pemudi di sini sangat ketat dan tidak sesuai dengan ajaran Islam”. Berkaitan dengan hambatan makan dan minim semuanya menjawab bahwa masakan Indonesia aneh dilidah, demikian juga minumanya. Beberapa mahasiswa menyikapi dengan masak sendiri. Hambatan kebahasaan pasti dihadapi oleh semua mahasiswa asal Thailand, tetapi bagaimana memecahkan masalah? Jawabanya relatif sama yaitu banyakbanyak berkomunikasi, belajar bertutur kata yang baik dan belajar tentang tata krama.

\section{SIMPULAN}

Banyak sekali kendala komunikasi yang dihadapi mahasiswa Thailand yang kuliah di Universitas Muhammadiyah Jember yang dapat dibedakan menjadi dua hambatan komunikasi yaitu hambatan akademik dan hambatan non akademik. Hambatan akademik yang paling dirasakan oleh mahasiswa Thailand bersumber dari keterbatasan penguasaan terhadap Bahasa Indonesia. Padahal Bahasa Indonesia merupakan pengantar dalam proses perkuliahan. Keadaan itu masih ditambah lagi dengan seringnya lingkungan akademik seperti dosen dan mahasiswa yang menggunakan bahasa daerah seperi Bahasa Madura dan Bahasa Jawa. Hambatan komunikasi yang bersifat non akademik atau lingkungan secara luas juga relatif sama yaitu bersumber dari keterbatasan penguasaan terhadap Bahasa Indonesia dan banyaknya masyarakat yang menggunakan bahasa daerah.

\section{Ucapan terima kasih}

Akhirnya peneliti mengucapkan syukur dan ucapan terima kasih kepada mahasiswa Thailand terutama yang menempuh pendidikan di Universitas Muhammadiyah Jember yang telah berkenan menjadi informan dalam penelitian ini. Disamping itu peneliti juga ingin mengucapkan terima kasih kepada Lembaga Pengabdian dan Pengembangan Kepada Masyarakat (LPPM) Universitas Muhammadiyah Jember dan juga semuga kolega di prodi dan fakultas. 
DAFTAR PUSTAKA

AloLiliweri, 2003, Dasar-Dasar Komunikasi Antarbudaya, Pustaka Pelajar, Yogyakarta.

, 2001, Gatra-Gatra

Komunikasi AntarBudaya, Pustaka

Pelajar, Yogyakarta.

AW, Suranto. 2011. Komunikasi Interpersonal, PT. Gahlia Ilmu, . Yogyakarta.

A.W.Widjaja, 1993, Komunikasi Dan Hubungan Masyarakat, Bumi Aksara, Jakarta.

Bungin, B.2001. Analisis Data Penelitian Kualitatif. PT Rajagrafindo Persada, Jakarta.

Budyatna, Muhammad. 2011. Teori

Komunikasi Antarpribadi. PT. Kencana Prenada Group.

Effendy, Onong Uchjana, Prof, Drs. 2008.

Dinamika Komunikasi. Bandung:

PT. Remaja Rosdakarya, Jakarta.

2007. Ilmu: Teori dan Filsafat

Komunikasi. PT. Citra Aditya Bakti, Bandung

2011. Ilmu Komunikasi Teori dan Praktek. PT. Remaja Roesdakarya, Bandung.

Faisal, Sanapiah 1990.Metode Penelitian,

Kanisius, Yogyakarta.
Liliweri, Alo, 2007, Dasar-Dasar Komunikasi Antarbudaya, Pustaka Pelajar, Yogyakarta _,1994, Komunikasi Verbal dan Nonverbal. PT Citra Aditya Bakti, Bandung.

Meleong, Lexy. J. 2007. Metodologi Penelitian Kualitatif, Remaja Rosdakarya, Bandung.

Mulyana, 2006, Deddy \& Jalaludin Rahmat, Komunikasi Antar Budaya Panduan Berkomunikasi dengan Orang-Orang Berbeda Budaya, Remaja Rosdakarya, Bandung.

Sendjaja, Sasa Djuarsa. 1994. Teori Komunikasi, Universitas Terbuka, Jakarta.

Stewart L. Tubbs dan Sylvia Moss, 1996 Human Communication : Kontekskonteks Komunikasi, Remaja Rosdakarya, Bandung.

Sugiono, 2009,Memahami Penelitian Kualitatif, Alfabeta, Bandung.

Suharsini, Arikunto.2010. Prosedur penelitian Suatu Pendekatan Praktik, Rineka Cipta, Jakarta. 